Creative Commons User License: CC BY-NC-ND

Abstracted by: EBSCOhost, Electronic Journals Service (EJS), Google Scholar, Journal Seek, Scientific Commons,

Food and Agricultural Organization (FAO), CABI and Scopus
Journal of Agricultural Extension

Vol. 23 (3) July, 2019

ISSN(e): 24086851; ISSN(Print); 1119944X

http://journal.aesonnigeria.org

http://www.ajol.info/index.php/iae

Email: editorinchief@aesonnigeria.org

\title{
Using Interpretive Structure Modelling in Developing an Organic Farming Sustainability Strategy in Indonesia
}

https://dx.doi.org/10.4314/jae.v23i3.17

\author{
Prasetyaningtyas, Sekar Wulan \\ School of Business, IPB University \\ Bogor, West Java, Indonesia \\ E-mail: sekarwprasetya@gmail.com +6285695335351
}

\section{Maaruf, Syamsul}

School of Business, IPB University

Bogor, West Java, Indonesia

E-mail: syamsul4958@gmail.com +6289697750647

\section{Sobir, Ridwani}

Faculty of Agriculture, IPB University

Bogor, West Java, Indonesia

E-mail: ridwanisobir@gmail.com +628128097381

\section{Hermawan, Aji}

School of Business, IPB University

Bogor,West Java, Indonesia

E-mail: ajiher@ipb.ac.id +628128638136

\begin{abstract}
This study determined key factors in developing a sustainability strategy for organic farming in Indonesia using Interpretive Structural Model. Data were taken using indepth interviews to stakeholders. Seven elements were identified: actor, core activities, obstacles, operational strategy, and the indicators of economy, social and environment. The connections between those specific elements that determined the problem or sub-problem were identified. A basic understanding of complex situations was developed to construct a corrective action to overcome the problems. Furthermore, the formulation of key factors in business strategies was established to increase the sustainability of organic farming in Indonesia
\end{abstract}

Keywords: Organic farming; sustainability strategies, interpretive structure modelling.

\section{Introduction}

In recent years, environmental issues have become the focus of society. The use of organic materials, known as organic farming, received more attention in agricultural activities,. Indonesia as one of the developing and emerging economy countries with approximately 252 million in population in 2015 and economic growth of $5.2 \%$ per annum (David and Ardiansyah, 2016) and has the potential to be among the largest producers and market for 
Creative Commons User License: CC BY-NC-ND

Abstracted by: EBSCOhost, Electronic Journals Service (EJS), Google Scholar, Journal Seek, Scientific Commons,

Food and Agricultural Organization (FAO), CABI and Scopus
Journal of Agricultural Extension

Vol. 23 (3) July, 2019

ISSN(e): 24086851; ISSN(Print); 1119944X

http://journal.aesonnigeria.org

http://www.ajol.info/index.php/iae

Email: editorinchief@aesonnigeria.org

organic products. According to the data from Indonesian government (Central Bureau of Statistics, 2012) Indonesia will experience a demographic bonus between 2020 and 2030. As a result, the number of productive-age people is increasing rapidly, therefore leading to an increase in income per capita among middle-class households (David and Ardiansyah, 2016).

Indonesia has 17 million hectares of vacant agricultural land (Hubeis et al., 2013). If those vacant lands were being used for organic land, then organic food export revenue from the 17-million-hectare land could reach US \$ 100 billion per year (Hubeis et al., 2013 ). Unfortunately, the majority of Indonesia organic farmers are small farmer with cultivation area less than 0.25 ha each; mostly organized individually; lack of technology information access and networking (Tridjaja, 2016). Some policy has been set up by the government to support organic agriculture in Indonesia. The Indonesian government undertook a program called "Go Organic 2010" aimed at raising national awareness of the benefits of organic farming (Nugraheni and Purnama 2013). The Ministry of Agriculture is promoting the growth of organic agriculture through this initiative as a form of "eco-agribusiness", targeting primarily export but also domestic markets. Organic standard was launched by Indonesia Organic Alliance (IOA) in 2005, based on the International Federation Organic Agriculture Movement and the Codex Alimentarius commission. The Government policy has been settled to develop, facilitate, and manage organic farming. There were programs which were focused on: technical supports and certification, market promotion, trade and industrial development, organic standard recognition, harmonization and cooperation, expanded market access, and strengthening of organic farmer organization. To show the commitment of the Government of Indonesia on organic development, in year 2007 has allocated some US\$ 3.23 million to support this programme. (Tridjaja, 2016).

Although the potential was big and there was support from the government, David and Ardiansyah (2016) in a meta-analysis of organic agricultural research in Indonesia stated that the condition of sustainability of organic agriculture in Indonesia is stagnant. According to the Indonesian Organic Alliance (2017), until 2014, only 67,426 ha of land was certified and considered as organic farmland. The total area of land considered organic compared to the total area of agricultural land in Indonesia is only $0.86 \%$ (Indonesia Organic Alliance, 2017).

In general, if the organic agriculture in Indonesia is developed, the average income earned by the Indonesian farmers from organic farming is around US $\$ 6,000$ per hectare (Hubeis et al., 2013). In terms of price, organic products in the international market range from 5-10 times the price of ordinary products and in addition to economic benefits, the development of organic products is labour intensive (Boons and Lüdeke-Freund, 2013). This labour intensive nature of organic farming allows to develop local potential and further enhance the capacity of the local environment. As a result, the creation of new jobs for locals contributes to rural economic development and social growth.

A strategy is needed to overcome the challenges of organic farming in Indonesia. Among methods that are commonly used in strategy making is the approach that was developed by Saxena et al. in 1992 (Attri et al., 2012) through Interpretive Structural Modeling (or ISM). This method is a group learning process where the strategy model is resulted in order to 
Creative Commons User License: CC BY-NC-ND

Abstracted by: EBSCOhost, Electronic Journals Service (EJS), Google Scholar, Journal Seek, Scientific Commons,

Food and Agricultural Organization (FAO), CABI and Scopus
Journal of Agricultural Extension

Vol. 23 (3) July, 2019

ISSN(e): 24086851; ISSN(Print); 1119944X

http://journal.aesonnigeria.org

http://www.ajol.info/index.php/iae

Email: editorinchief@aesonnigeria.org

describe complex matter from a particular condition of system through pattern that was designed systematically by using graphics and words (Eriyatno, 2012). The ISM method is an interactive learning process where a group of elements is arranged in a comprehensive system model. The ISM helps in determining the sequence and the goal on a complex relationship among elements in the system (Indrawati, 2013).

According to Attri et al. (2012), the ISM method can be used to develop several structure types, includes effect (support or neglect), priority ('more important than' or 'should have been studied before') and idea categorization (e.g. 'included in the same category as'). The strategy making structure in ISM consists of data of elements, data of sub-elements and data of contextual relationship. Data of elements describes the elements contained in the system of organic farming, while the sub-elements data describes the sub-elements contained in each element. Those data are then used as database in model of strategy development. Result of the strategy model is in the form of main priority of all chosen subelements alternatives.

According to Attri et al. (2012), strategy development structuring can be analysed based on nine elements, which are: goals, needs, main obstacle, indicator of success, involved institutions in the implementation, sectors of affected communities, possible changes, activity needed in action plan, and activity dimensions in order to evaluate result that was achieved by each activity. However, not all elements are used in doing an analysis. Usually researcher only analyse two to five elements. (Budi et al., 2011; Jaya et al., 2013; Hsu et al., 2015; Murtadlo and Utomo,, 2014).

\section{Methodology}

The data collecting process was carried out in an organic horticulture farming area located in Cipanas, West Java, Indonesia (The latitude of Cipanas, West Java, Indonesia is 6.734679, and the longitude is 107.041252. Cipanas, West Java, Indonesia is located at Indonesia country in the cities place category with the gps coordinates of $6^{\circ} 44^{\prime} 4.8444^{\prime \prime} \mathrm{S}$ and $107^{\circ} 2^{\prime} 28.5072^{\prime \prime} \mathrm{E}$. ) which has been operating for around 8 years. This region was chosen because it represents most of the horticulture organic area in this part of Indonesia.

Data collection was conducted from October to December 2018 while analysis and data processing was carried out from January to March 2019. In-depth interviews and Focus Group Discussions (FGD) were done to gather data from all stakeholders (5 farmers, 1 operational manager, 1 financial manager, 1 training manager and 1 owner) in the farm area. Data were analysed using Interpretive Structure Modelling to get to know the key factors, consist of the drivers and dependence factors in the farm's strategy. Face validity was done to validate the data obtained by conducting in-depth interviews with 9 experts consisting of 2 academics at Bogor Agricultural Institute, 1 expert staffs of the Agriculture Department, 1 Director of the Indonesian Organic Alliance, and 2 organic business owners who have carried out their business for more than 15 years.

\section{Interpretive Structural Model}

The Interpretive Structural Model is a classic interactive learning process that converts basic formulation models into clearly defined and focused ones. The ISM is a methodology to identify connections between specific items that determine the problem or sub-problem. The 
Creative Commons User License: CC BY-NC-ND

Abstracted by: EBSCOhost, Electronic Journals Service (EJS), Google Scholar, Journal Seek, Scientific Commons,

Food and Agricultural Organization (FAO), CABI and Scopus
Journal of Agricultural Extension

Vol. 23 (3) July, 2019

ISSN(e): 24086851; ISSN(Print); 1119944X

http://journal.aesonnigeria.org

http://www.ajol.info/index.php/iae

Email: editorinchief@aesonnigeria.org

ISM concentrates on breaking down complex systems into several simple subsystems and provides a basic understanding of complex situations, and for constructing corrective actions to solve problems. The ISM is widely used in the formulation of operational business strategies (Fadhil et al., 2018).

The ISM is one of the modelling techniques for strategic policy. Attri et al. (2012) stated that the ISM technique is related to the interpretation of the whole object or systematic system representation and the application of repeated graph theory. In this study, ISM was used to form a hierarchy of internal and external elements that are strategic for the development of organic farming in Indonesia. The flow diagram on preparing ISM can be seen in Figure 1. Data processing was done by using Decision Support System (DSS) V.1 PRE-NET (Policy Research Expert Network) Software (Policy Research Expert Network, 2010).

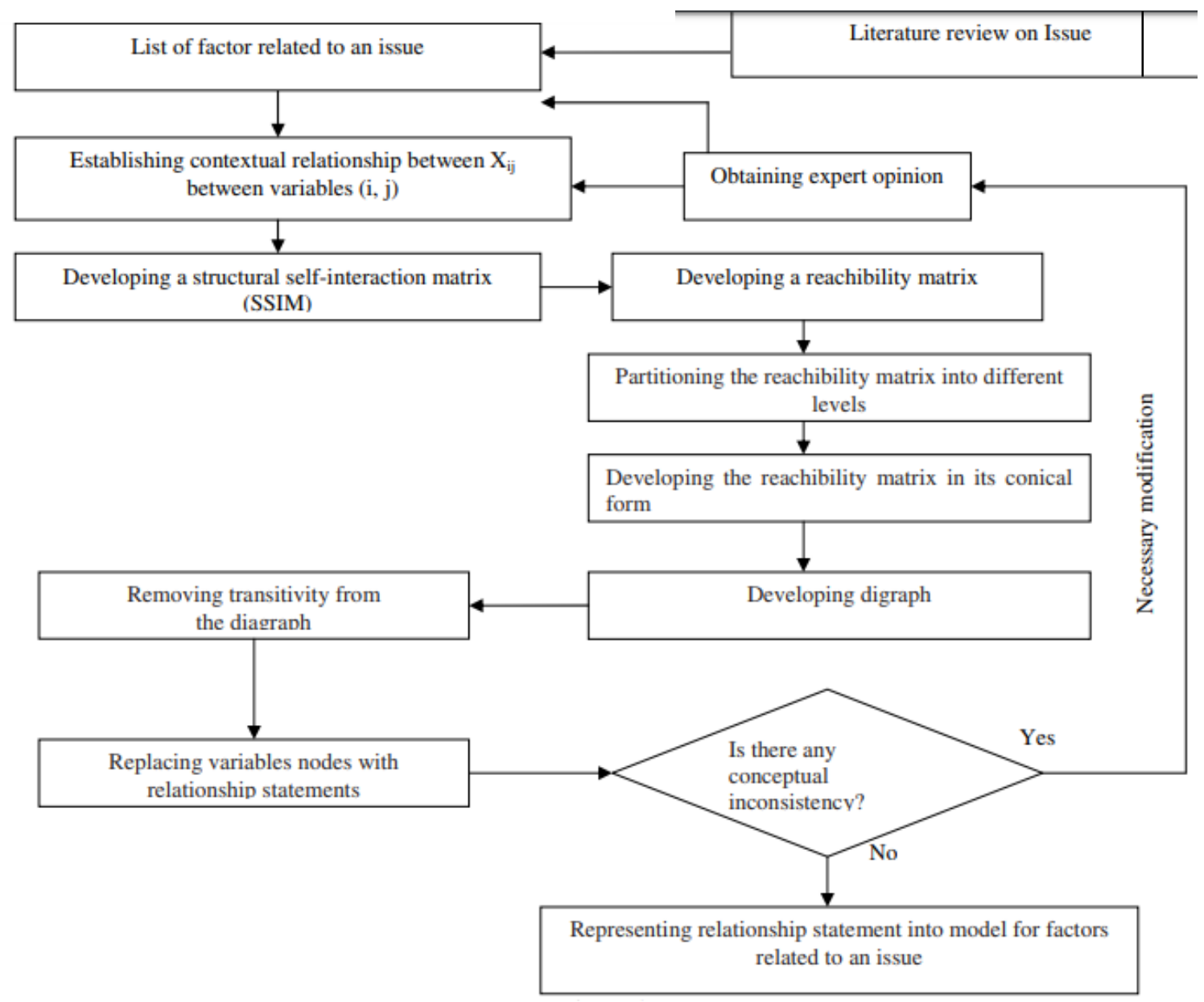

Figure 1: Flow diagram for preparing ISM model (Attri et al., 2012)

The procedure for implementing ISM is as follow:

(a) Identify the elements and sub-elements through in-depth interviews with experts, fields of study, and literature reviews. 
Creative Commons User License: CC BY-NC-ND

Abstracted by: EBSCOhost, Electronic Journals Service (EJS), Google Scholar, Journal Seek, Scientific Commons,

Food and Agricultural Organization (FAO), CABI and Scopus
Journal of Agricultural Extension

Vol. 23 (3) July, 2019

ISSN(e): 24086851; ISSN(Print); 1119944X

http://journal.aesonnigeria.org

http://www.ajol.info/index.php/iae

Email: editorinchief@aesonnigeria.org

(b) Formulate contextual relationships among elements that are established using the Structural Self Interaction Matrix (SSIM). This formulation is carried out by evaluating the contextual relationship in the matrix pair comparison, using the symbols $\mathrm{V}, \mathrm{A}, \mathrm{X}$ and O, which are:

$\mathrm{V}$ if $e i j=1$ and $e j i=0$; $\mathrm{A}$ if $e i j=0$ and $e j i=1 ; \mathrm{X}$ if $e i j=1$ and $e j i=1$; $\mathrm{O}$ if $e i j=0$ and $e j i=$ 0 .

(c) Change the SSIM matrix into the Reachability Matrix and then into the binary matrix. This is a process of interpreting $\mathrm{V}, \mathrm{A}, \mathrm{X}$, and $\mathrm{O}$ into numbers 1 and 0 , and then further corrected until it becomes a closed-loop matrix that encounters the transitivity rule, which is the completeness of the ordinary loop, where, for example, A affects $B$, and $B$ affects $\mathrm{C}$, so A must affect $\mathrm{C}$. Reachability Matrix is done to obtain driving force and dependency strength. The Reachability Matrix that met the Transitivity Rules could continue to select the partition level.

(d) Formulate Canonical Matrix, which is a grouping of elements at the same level. The canonical matrix is done by arranging variables based on the level generated from the partition level, in the form of the final reachability matrix table.

(e) Analyse the driving force and dependency power of a variable through Cross-Impact Matrix Multiplication Applied to Classification (MICMAC) Analysis, so that the results of the analysis were identified as key variables in the system. Variables in the MICMAC Analysis were classified into 4 sectors (Figure 2), namely:

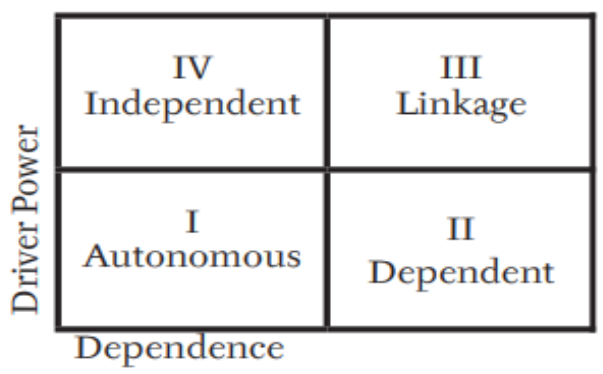

Figure 2: MICMAC analysis

i. Sector 1 is an autonomous factor (weak driver - weak dependent variable). Elements included in this sector are elements that have weak driving power and weak dependency. This element is not related to the system and may have only a few connections, so the element will be removed from the system.

ii. Sector 2 consists of dependent factors (weak drivers - very dependent variables). Elements included in this sector are elements that have a weak driver power and strong dependency. Elements in this sector are dependent elements.

iii. Sector 3 is the connecting factor (strong driver - very dependent variable). Elements included in this sector are elements that have a strong driving force and strong dependency. Elements in this sector are elements that need to be studied carefully because the relationships between elements are unstable. 
Creative Commons User License: CC BY-NC-ND

Abstracted by: EBSCOhost, Electronic Journals Service (EJS), Google Scholar, Journal Seek, Scientific Commons,

Food and Agricultural Organization (FAO), CABI and Scopus
Journal of Agricultural Extension

Vol. 23 (3) July, 2019

ISSN(e): 24086851; ISSN(Print); 1119944X

http://journal.aesonnigeria.org

http://www.ajol.info/index.php/iae Email: editorinchief@aesonnigeria.org

iv. Sector 4 is an Independent factor (strong driver - weak dependent variable). Elements included in this sector are elements that have a strong driving force and have a weak dependency. Elements in this sector are key element forming a model.

(f) Compose Digraph matrix (Directional Graph), a graph of elements that interconnected directly to the hierarchy level.

(g) Create a Structural Model, the ISM model that results from the transfer of all element numbers with the actual element description, so it can give an exceptionally clear depiction of an arrangement of a component and the relationship stream.

In the initial step of this strategy, construction of sustainable organic farming in Indonesia was done by determining the list of main elements. Based on the experts' opinion, seven main elements, whose strategies are considered to be most important to formulate, were selected, they are: (1) the actors or stakeholders in the farm; (2) farm activities; (3) obstacles that occur; (4) strategy applied; (5) economic indicator used; (6) social indicator used; (7) environmental indicator used. The collection of experts' opinions from each element resulted in a number of strategic sub-elements for the construction of sustainability strategies in organic farming in Indonesia. The Elements and sub-elements used in this research are explained in Table. 1 
Creative Commons User License: CC BY-NC-ND

Abstracted by: EBSCOhost, Electronic Journals Service (EJS), Google Scholar, Journal Seek, Scientific Commons,

Food and Agricultural Organization (FAO), CABI and Scopus
Journal of Agricultural Extension

Vol. 23 (3) July, 2019

ISSN(e): 24086851; ISSN(Print); 1119944X

http://journal.aesonnigeria.org

http://www.ajol.info/index.php/iae

Email: editorinchief@aesonnigeria.org

\section{Table 1. Identification of element and sub-elements}

\begin{tabular}{|c|c|}
\hline Elements & Sub-elements \\
\hline Actors & $\begin{array}{l}\text { E1 Internal farmers } \\
\text { E2 Plasma farmers (farmers who own their own land but sell } \\
\text { their crops to Cipanas Organic farm) } \\
\text { E3 Farm staff } \\
\text { E4 Farm manager } \\
\text { E5 Foundation }\end{array}$ \\
\hline Activities & $\begin{array}{l}\text { E1 Farm Operational } \\
\text { E2 Mentoring plasma farmers } \\
\text { E3 Organic farming education } \\
\text { E4 Agritourism } \\
\text { E5 Financial support from foundation }\end{array}$ \\
\hline Obstacles & $\begin{array}{l}\text { E1 Weather } \\
\text { E2 Lack of human resources in farm } \\
\text { E3 Lack of human resources in marketing } \\
\text { E4 Unstable demand } \\
\text { E5 Unstable supply } \\
\text { E6 Pest }\end{array}$ \\
\hline $\begin{array}{l}\text { Farm Operational } \\
\text { Strategies }\end{array}$ & $\begin{array}{l}\text { E1 Direct marketing to export markets } \\
\text { E2 Direct marketing to hotel and restaurant } \\
\text { E3 Farm innovation } \\
\text { E4 Open farm management } \\
\text { E5 Simple farm organizational structure } \\
\text { E6 Digital Marketing }\end{array}$ \\
\hline Economic indicators & $\begin{array}{l}\text { E1 Employment in rural areas } \\
\text { E2 Increase in farmers' revenue } \\
\text { E3 Commodity price guarantee }\end{array}$ \\
\hline Social indicators & $\begin{array}{l}\text { E1 Food security } \\
\text { E2 Food quality } \\
\text { E3 Community development }\end{array}$ \\
\hline $\begin{array}{l}\text { Environmental } \\
\text { indicators }\end{array}$ & $\begin{array}{l}\text { E1 Water quality } \\
\text { E2 Air quality } \\
\text { E3 Land quality }\end{array}$ \\
\hline
\end{tabular}

By using MICMAC analysis, we know that the most independent variable with the highest driven power is located on sector 4. Attri et al. (2012) stated that the sub-elements that have the strongest driver power in the system will affects other sub-elements, thus it can be considered as the key factors in the system. The result of MICMAC analysis on 7 elements of organic farming in Indonesia can be seen in Table 2. 
Creative Commons User License: CC BY-NC-ND

Abstracted by: EBSCOhost, Electronic Journals Service (EJS), Google Scholar, Journal Seek, Scientific Commons,

Food and Agricultural Organization (FAO), CABI and Scopus
Journal of Agricultural Extension

Vol. 23 (3) July, 2019

ISSN(e): 24086851; ISSN(Print); 1119944X

http://journal.aesonnigeria.org

http://www.ajol.info/index.php/iae

Email: editorinchief@aesonnigeria.org

Table 2. Findings of key sub-element based on MICMAC analysis

\begin{tabular}{|c|c|c|c|c|}
\hline \multirow{3}{*}{$\begin{array}{l}\text { Sector } \\
\text { Characteristic }\end{array}$} & 1 & 2 & 3 & 4 \\
\hline & $\begin{array}{l}\text { autonomous } \\
\text { factor }\end{array}$ & $\begin{array}{l}\text { dependent } \\
\text { factors }\end{array}$ & connecting factor & $\begin{array}{l}\text { independent } \\
\text { factor }\end{array}$ \\
\hline & $\begin{array}{l}\text { (weak driver - } \\
\text { weak } \\
\text { dependent } \\
\text { variable) }\end{array}$ & $\begin{array}{l}\text { (weak drivers - } \\
\text { very dependent } \\
\text { variable) }\end{array}$ & $\begin{array}{l}\text { (strong driver - } \\
\text { very dependent } \\
\text { variable) }\end{array}$ & $\begin{array}{l}\text { (strong driver - } \\
\text { weak } \\
\text { dependent } \\
\text { variable) }\end{array}$ \\
\hline Description & $\begin{array}{l}\text { May be } \\
\text { removed from } \\
\text { the system }\end{array}$ & $\begin{array}{l}\text { Dependent to } \\
\text { the key element }\end{array}$ & $\begin{array}{l}\text { Need to be studied } \\
\text { carefully because } \\
\text { the relationships } \\
\text { between elements } \\
\text { are unstable }\end{array}$ & Key element \\
\hline
\end{tabular}

Sub-element:

\begin{tabular}{|c|c|c|c|c|c|}
\hline & \multicolumn{3}{|c|}{ a. Actors } & \multirow{2}{*}{$\begin{array}{ll}\text { - } & \text { Farmers } \\
\text { - } & \text { Plasma farmers } \\
\text { - Staffs } \\
\text { - } & \text { Manager } \\
\text { - } & \text { Farm } \\
& \text { Operational } \\
\text { - Organic } & \text { farming } \\
& \text { education } \\
\text { - } & \text { Agritourism }\end{array}$} & \multirow{2}{*}{$\begin{array}{l}\text { Foundation } \\
\begin{array}{l}\text { Financial support from } \\
\text { the foundation }\end{array}\end{array}$} \\
\hline b. & $\begin{array}{l}\text { Core } \\
\text { activities }\end{array}$ & & $\begin{array}{l}\text { Mentoring } \\
\text { plasma farmers }\end{array}$ & & \\
\hline c. & Obstacles & $\begin{array}{l}\text { - Weather } \\
\text { - Unstable } \\
\text { demand } \\
\text { - Pest }\end{array}$ & & & $\begin{array}{l}\text { - Lack of human } \\
\text { resources in farm } \\
\text { - Lack of human } \\
\text { resources in marketing } \\
\text { - Unstable supply }\end{array}$ \\
\hline d. & $\begin{array}{l}\text { Farm } \\
\text { operational } \\
\text { strategies }\end{array}$ & & $\begin{array}{l}\text { - simple farm } \\
\text { organizational } \\
\text { structure } \\
\text { - digital } \\
\text { marketing }\end{array}$ & & $\begin{array}{l}\text { - } \text { direct marketing to the } \\
\text { export markets } \\
\text { - direct marketing to } \\
\text { hotels and restaurants } \\
\text { - farm innovation } \\
\text { - open farm } \\
\text { management }\end{array}$ \\
\hline e. & $\begin{array}{l}\text { Economic } \\
\text { indicators }\end{array}$ & & $\begin{array}{l}\text { increased } \\
\text { farmers revenue }\end{array}$ & $\begin{array}{l}\text { commodity prices } \\
\text { guarantees }\end{array}$ & $\begin{array}{l}\text { - increasing employment } \\
\text { opportunities in rural } \\
\text { area }\end{array}$ \\
\hline f. & $\begin{array}{l}\text { Social } \\
\text { indicators }\end{array}$ & & $\begin{array}{l}\text { rural } \\
\text { communities' } \\
\text { development }\end{array}$ & & $\begin{array}{l}\text { - food security } \\
\text { - food quality }\end{array}$ \\
\hline & $\begin{array}{l}\text { Environmenta } \\
\text { I indicators }\end{array}$ & & & $\begin{array}{l}\text { - } \quad \text { water quality } \\
\text { - } \quad \text { air quality } \\
\text { - } \quad \text { soil quality }\end{array}$ & \\
\hline
\end{tabular}


Creative Commons User License: CC BY-NC-ND

Abstracted by: EBSCOhost, Electronic Journals Service (EJS), Google Scholar, Journal Seek, Scientific Commons,

Food and Agricultural Organization (FAO), CABI and Scopus
Journal of Agricultural Extension

Vol. 23 (3) July, 2019

ISSN(e): 24086851; ISSN(Print); 1119944X

http://journal.aesonnigeria.org

http://www.ajol.info/index.php/iae

Email: editorinchief@aesonnigeria.org

From the table, the key element for actor is the foundation. Meanwhile the key element for the activities is the funding from the foundation. The key elements for obstacles, that might affect negatively to the strategies are the quality of human resources and the unstable supply of products. The key elements for the operational strategies are the direct marketing to the community, hotel and restaurants chain. Innovation and farm management models are also considered are the key factors. In terms of economic indicators, the employment rate for rural area is the key factor that need to be considered in strategy making. For the social indicators, food security and food quality are the key factors, meanwhile for the environmental indicators, none of the sub- elements mentioned considered as the key factors.

\section{Result and Discussion}

For actors element, key sub-element that has highest driven power was foundation. It indicated that foundation owned the most important and strategic roles in organic farming institutional system. The foundation in this case got the full support from NGO. Attri et al. (2012) stated that NGOs support and assistance to organic farmers often originated from church or development organizations and have been particularly important in developing countries. They have promoted organic agriculture in the first place as an appropriate technology for small-scale farmers, emphasizing low use of external inputs, independence from agri-business, and care for natural resources as well as the potential for food security and economic viability. Many NGOs have also initiated marketing activities, including smallscale processing, to include economic sustainability in their strategies for agricultural development (Attri et al., 2012).

The results of the ISM analysis on the core activity element show a close relationship with the results of the ISM analysis on actor elements. Since the foundation is the most important player in this sustainability strategy construction, the core activity in the farm relied much on the support funding from the foundation. International Federation of Organic Agriculture Movements (IFOAM) in 2016, mentioned that only three percent of organic agriculture farmers were completely able to meet their funding needs; thus financial support is needed. On the other hand, organic agriculture is a low external input regimen. This implies that there will be limited need to bring in purchased inputs for cultivation and will, therefore, mean a reduction in financial outgo, obviously not a scenario to whet the appetite of bankers in developing countries (United Nations Conference on Trade and Development, 2016)

Since financial support was not a main problem in Cipanas Organic Farming, then human resources quality appeared to become the prominent obstacle. Both of these issues became interesting to be observed that the study regarding strategy construction is always much related to the human resources. It means that strategy construction and human resources is an inseparable entity. Studies about close connection between strategy and human resources were also reported by other researchers (Fadhil et al., 2018; Murtadlo and Utomo, 2014; Jaya et al., 2013; ).

In element of farm operational strategy, choosing a right marketing channel and innovation in farm is the most important key in construction of sustainability strategy in organic farming. 
Creative Commons User License: CC BY-NC-ND

Abstracted by: EBSCOhost, Electronic Journals Service (EJS), Google Scholar, Journal Seek, Scientific Commons,

Food and Agricultural Organization (FAO), CABI and Scopus
Journal of Agricultural Extension

Vol. 23 (3) July, 2019

ISSN(e): 24086851; ISSN(Print); 1119944X

http://journal.aesonnigeria.org

http://www.ajol.info/index.php/iae

Email: editorinchief@aesonnigeria.org

Hubeis et al. (2013) stated that in Indonesia's organic farming market, having the right marketing channel can help farmers get the premium price, thus increase their income. Also, innovation is critical for all agri-food systems, including organic, and these innovations must be based on a system approach. The category of innovation is not limited to technical aspects but also relies on the creativity and diversity in perspectives of researchers, social networks and institutions (Ardakani et al., 2016).

In developing a sustainable strategy in the organic farming industry, it is important to find an accurate model of conjunction between strategy and sustainability indicator. Three indicators used in this research: economic, social and environment. All stakeholders in this research agreed that quality of air, land, water, and products should be priority in the construction of strategy in organic farming. The employment of rural people also plays important role in designing the strategy.

\section{Conclusion and Recommendation}

In terms of actors; the foundation-NGO is the prominent factor that need to be included in strategy making. For farm operational strategy; the key factors were to choose the right marketing channel and boost the innovation process in the farm. In terms of obstacles; the quality of human resources and pest management were the key factors that need to be tackled in the strategy making. In terms of sustainability indicators that being used in strategy making; employment in rural areas, food quality, and the quality of air, water, and land were the key factors that need to be prioritized. Result from these key factors identification became valuable reference for follow-up plan of organic farming industry in Indonesia, and also could be a model for sustainability strategy development of other industry.

\section{Acknowledgements}

The authors extend their appreciation to the South East Asian Regional Centre for Graduate Study and Research in Agriculture (Searca) for funding this work through graduate research scholarship.

\section{References}

Ardakani, M.R., Barberi, P., \& Boehm, H. (2016). Organic agriculture is innovation with research. Organic Agriculture. https://doi.org/doi:10.1007/s13165-016-0171-5.

Attri, R., Dev, N., \& Sharma, V. (2012). Interpretive structural modelling (ISM) approach: An overview. Research Journal of Management Sciences, 2(2).

Boons, F. \& Lüdeke-Freund, F. (2013). Business models for sustainable innovation: state-ofthe-art and steps towards a research agenda. Journal of Cleaner Production, 45: 9-19. https://doi.org/doi:10.1016/j.jclepro.2012.07.007. 
Creative Commons User License: CC BY-NC-ND

Abstracted by: EBSCOhost, Electronic Journals Service (EJS), Google Scholar, Journal Seek, Scientific Commons,

Food and Agricultural Organization (FAO), CABI and Scopus
Journal of Agricultural Extension

Vol. 23 (3) July, 2019

ISSN(e): 24086851; ISSN(Print); 1119944X

http://journal.aesonnigeria.org

http://www.ajol.info/index.php/iae

Email: editorinchief@aesonnigeria.org

Budi, L.S., Maarif, M.S., Sailah, I., \& Raharja, S. (2009). Strategy for Selecting the Institutional Model and Financial Feasibility of Sesame Agroindustry. Jurnal Teknologi Industri Pertanian, 19(2): 56-63.

Central Bureau of Statistics. (2012). Social Statistical Analysis: Demographic Bonuses. available online:

https://www.bps.go.id/publication/2012/11/30/4c36afac847c656d4db93040/analisis -statistik-sosial--bonus-demografi-dan-pertumbuhan-ekonomi-.html.

David, W. \& Ardiansyah. (2016). Organic agriculture in Indonesia: challenges and opportunities. Org.agr. doi: https://doi.org/doi:10.1007/s13165-016-0160-8.

Eriyatno. (2012). Science of System, improving management quality and effectivity. Guna Widya Publishing, Surabaya.

Fadhil, R., Maarif, M., Bantacut, T., \& Hermawan, A. (2018). Formulation for development strategy of Gayo Coffee Agroindustry Institution using Interpretive Structural Modeling (ISM). Acta Universitatis Agriculturae et Silviculturae Mendelianae Brunensis, 66(2): 487-495.

Hsu, D.W.L., Shen, Y.C., Yuan, B.J.C, \& Chou, J.C. (2015). Toward successful commercialization of university technology: Performance drivers of university technology transfer in Taiwan. Technological Forecasting and Social Change, 92: 25-39.

Hubeis. M., Najib, M., Widyastuti, H., \& Wijaya, N.H. (2013). Farmer-based high valueadded organic food production strategies. Jurnal IImu Pertanian Indonesia (JIPI), 18 (3): 194-199.

Indonesian Organic Alliance. 2017. Indonesian Organic Agriculture Statistics 2016. Bogor, Indonesia.

Indrawati, C.D. (2013). Structural Modelling of Supply Chain Risk Linkage with interpretive structural modelling (ISM) approach]. In: Prosiding Seminar Nasional Manajemen Teknologi XVII, MMT-ITS.A25: 1-12.

International Federation of Organic Agriculture Movements (IFOAM). (2016). The world of organic agriculture. Statistic and emerging trends 2016 available online: http://www.organic-world.net/yearbook/yearbook-2016.html.

Jaya, R., Machfud, M., \& Ismail, M. (2013). Application of ISM and ME-MCDM Techniques for the Identification of Stakeholders Position and Alternatives Activities to Improve Quality of Gayo Coffee. Jurnal Teknologi Industri Pertanian, 21(1): 1-8. 
Creative Commons User License: CC BY-NC-ND

Abstracted by: EBSCOhost, Electronic Journals Service (EJS), Google Scholar, Journal Seek, Scientific Commons,

Food and Agricultural Organization (FAO), CABI and Scopus

http://eoi.citefactor.org/10.11226/v23i3
Journal of Agricultural Extension

Vol. 23 (3) July, 2019

ISSN(e): 24086851; ISSN(Print); 1119944X

http://journal.aesonnigeria.org

http://www.ajol.info/index.php/iae Email: editorinchief@aesonnigeria.org

Murray, E.V. (2006) Financing Organic Agriculture - Options \& Prospects. National Seminar on Organic Agriculture held on November 20 - 21, 2006 at Kochi.

Murtadlo, K. \& Utomo, D. (2014). Interpretative structural modeling institutional land use of agricultural in Pasuruan. Journal of Economics and Sustainable Development, 5(12): 113-122.

Nugraheni S, Purnama AFD (2013) Problem and prospect of organic farming in Indonesia: lesson from five districts in West Java Province. 23th Pacific Conference of the Regional Science Association International, July 2-4, 2013.

Tridjaja, N.O. (2016). Diversity of organic produce in Indonesia. Journal of Food Science and Engineering 6(1).

United Nations Conference on trade and development (UNCTAD). (2016). Available online: https://unctad.org/en/PublicationsLibrary/webditcted 2016 d6en.pdf (Accessed on 27 February 2019). 